\title{
In Situ Formation of AgCo Stabilized on Graphitic Carbon Nitride and Concomitant Hydrolysis of Ammonia Borane to Hydrogen
}

\author{
Qi Wang ${ }^{1}$, Caili Xu ${ }^{1}$, Mei Ming ${ }^{1}$, Yingchun Yang ${ }^{2}$, Bin $\mathrm{Xu}^{3}$, Yi Wang ${ }^{1, *}$, Yun Zhang ${ }^{1}$, Jie Wu ${ }^{1}$ \\ and Guangyin Fan ${ }^{1, *}$ \\ 1 College of Chemistry and Materials Science, Sichuan Normal University, Chengdu 610068, China; \\ wangqi@sicnu.edu.cn (Q.W.); cailixu@sicnu.edu.cn (C.X.); meiming@sicnu.edu.cn (M.M.); \\ zhangyun@sicnu.edu.cn (Y.Z.); wujie@sicnu.edu.cn (J.W.) \\ 2 College of Resources and Environment, Chengdu University of Information Technology, Chengdu 610225, \\ China; yangyingchun@cuit.edu.cn \\ 3 School of Chemical and Environmental Engineering, Sichuan University of Science \& Engineering, \\ Zigong 643000, China; jwdxb@suse.edu.cn \\ * Correspondence: yiwang@sicnu.edu.cn (Y.W.); fanguangyin@sicnu.edu.cn (G.F.); \\ Tel.: +86-28-8476-0802 (G.F.)
}

Received: 29 March 2018; Accepted: 23 April 2018; Published: 26 April 2018

\begin{abstract}
The development of highly-efficient heterogeneous supported catalysts for catalytic hydrolysis of ammonia borane to yield hydrogen is of significant importance considering the versatile usages of hydrogen. Herein, we reported the in situ synthesis of AgCo bimetallic nanoparticles supported on $\mathrm{g}_{-} \mathrm{C}_{3} \mathrm{~N}_{4}$ and concomitant hydrolysis of ammonia borane for hydrogen evolution at room temperature. The as-synthesized $\mathrm{Ag}_{0.1} \mathrm{Co}_{0.9} / \mathrm{g}-\mathrm{C}_{3} \mathrm{~N}_{4}$ catalysts displayed the highest turnover frequency (TOF) value of $249.02 \mathrm{~mol} \mathrm{H}_{2} \cdot\left(\mathrm{mol}_{\mathrm{Ag}} \cdot \mathrm{min}\right)^{-1}$ for hydrogen evolution from the hydrolysis of ammonia borane, which was higher than many other reported values. Furthermore, the $\mathrm{Ag}_{0.1} \mathrm{Co}_{0.9} / \mathrm{g}-\mathrm{C}_{3} \mathrm{~N}_{4}$ catalyst could be recycled during five consecutive runs. The study proves that $\mathrm{Ag}_{0.1} \mathrm{Co}_{0.9} / \mathrm{g}-\mathrm{C}_{3} \mathrm{~N}_{4}$ is a potential catalytic material toward the hydrolysis of ammonia borane for hydrogen production.
\end{abstract}

Keywords: graphitic carbon nitride; bimetallic catalyst; ammonia borane; hydrogen generation

\section{Introduction}

The widespread applications of fossil fuels result in the resource exhaustion and serious environmental pollution. Hydrogen has attracted increasing attention as a clean and renewable energy carrier [1]. However, the difficulties in controllable storage and safe delivery of hydrogen restrict its applications entirely. Chemical hydrides are widely investigated as raw materials to produce hydrogen [2-8], among which ammonia borane (AB) has been proven to be a promising hydrogen storage material to generate hydrogen. Hydrogen can be stoichiometrically produced with appropriate catalysts.

For the hydrolysis of AB, noble metals, such as Pt [9,10], Rh [11], Ru [5,7,12-15], and Pd [15,16], are intensively studied as the catalytic active sites, while the less expensive metals, such as $\mathrm{Au}$ and $\mathrm{Ag}$, are rarely explored because of their low catalytic activities. To promote their catalytic performances, and simultaneously reduce the usage of these metals, bimetallic catalysts with earth-abundant and low-cost metals have aroused much attention because of their enhanced catalytic activity toward the hydrolysis of $\mathrm{AB}$ in aqueous solution. Various supports, including graphene and metal-organic-frameworks, are explored to prepare supported catalysts for the hydrolysis of 
AB. For example, Ag@Co/graphene was prepared and selected as the catalyst for the hydrolysis of $\mathrm{AB}$ with a turnover frequency $(\mathrm{TOF})$ of $102.4 \mathrm{~mol} \mathrm{H}_{2} \cdot\left(\mathrm{mol}_{\mathrm{Ag}} \cdot \mathrm{min}\right)^{-1}$ [17]. The AuCo@MIL-101 [18] catalyst reported by Xu et al. exhibited a TOF value of $23.5 \mathrm{~mol} \mathrm{H}_{2} \cdot\left(\mathrm{mol}_{\mathrm{Au}} \cdot \mathrm{min}\right)^{-1}$. The Au-Co@CN nanoparticles prepared by Guo et al. displayed a TOF of $48.3 \mathrm{~mol} \mathrm{H}_{2} \cdot\left(\mathrm{mol}_{\mathrm{Au}} \cdot \mathrm{min}\right)^{-1}$ [19]. Despite these advances, the catalytic performance of the Ag- and Au-based catalysts are still not satisfactory enough and developing catalysts with high efficiencies is still challenging.

As is well-known, the catalytic property of a heterogeneous catalyst is closely correlated to the nature of the catalyst support [20]. Synthesis of catalyst supports in a convenient and inexpensive way is very attractive for practical applications. Graphitic-carbon nitride $\left(\mathrm{g}-\mathrm{C}_{3} \mathrm{~N}_{4}\right)$ synthesized through the pyrolysis of inexpensive urea is such a supporting material with superior chemical and physical properties [21], which can provide more active sites for reaction [22]. Therefore, $g-\mathrm{C}_{3} \mathrm{~N}_{4}$ is widespreadly applied as electrochemical catalysts [21,23] and photocatalysts [24,25]. Herein, we reported the in situ formation of an AgCo bimetallic catalyst and concomitant hydrolysis of AB to produce hydrogen at room temperature $\left(25^{\circ} \mathrm{C}\right)$. The AgCo bimetallic catalyst displayed an outstanding performance toward the catalytic hydrolysis of $\mathrm{AB}$. A very high TOF of $249.02 \mathrm{~mol} \mathrm{H}_{2} \cdot\left(\mathrm{mol}_{\mathrm{Ag}} \cdot \mathrm{min}\right)^{-1}$ was observed because of the synergistic effect of Ag and Co metals, as well as the interaction between metal and support. The present work may offer new opportunity for design and synthesis of highly-active catalysts with $\mathrm{g}-\mathrm{C}_{3} \mathrm{~N}_{4}$ as the catalyst support for various catalytic applications.

\section{Experimental}

\subsection{Materials and Methods}

$\mathrm{CoCl}_{2} \cdot 6 \mathrm{H}_{2} \mathrm{O}(\mathrm{AR})$ was purchased from Aladdin Industrial Inc. (Shanghai, China). $\mathrm{AgNO}_{3}(\mathrm{AR})$ was provided by Tianjin North Industrial (Tianjin, China). AB complex (90\%) and urea were bought form Sigma-Aldrich (St. Louis, MO, USA). All the chemicals were used without further purification. Ultrapure water was used in all tests.

The morphology and particle sizes of $\mathrm{Ag}_{0.1} \mathrm{Co}_{0.9} / \mathrm{g}-\mathrm{C}_{3} \mathrm{~N}_{4}$ and recycled $\mathrm{Ag}_{0.1} \mathrm{Co}_{0.9} / \mathrm{g}-\mathrm{C}_{3} \mathrm{~N}_{4}$ were measured by Transmission electron microscopy (TEM) with FEI Tecnai G20 (Hillsboro, OR, USA) operating at $200 \mathrm{kV}$. Powder X-ray diffraction (XRD) patterns were recorded by a Panalytical X'Pert PRO X-ray diffractometer (Egham, Surrey, UK) with $\mathrm{Cu} \mathrm{K} \alpha$ radiation operated at $40 \mathrm{kV}$ and $40 \mathrm{~mA}$. X-ray photoelectron spectroscopy (XPS) spectra were collected on a Thermo ESCALAB 250 Axis Ultra spectrometer (Waltham, MA, USA) with a monochromatic Al K $\alpha$ source $(h v=1486.6 \mathrm{eV})$. Fourier transform infrared (FTIR) spectra (BRUKER VERTEX70, GER) in the $400-4000 \mathrm{~cm}^{-1}$ region were obtained on a Thermo Nicolet 870 instrument. Inductively coupled plasma-optical emission spectrometry (ICP-OES) analysis was carried out on SPECTRO ARCOS spectrometer (SPECTRO, Kleve, Germany).

\subsection{Preparation of $A g_{x} \mathrm{Co}_{1-x} / g-C_{3} N_{4}$}

g- $\mathrm{C}_{3} \mathrm{~N}_{4}$ was synthesized via the pyrolysis method by using urea as the raw material. Specifically, urea was deposited in a porcelain crucible and heated at $300^{\circ} \mathrm{C}$ for $1 \mathrm{~h}$, and followed by calcining at $550{ }^{\circ} \mathrm{C}$ for another $3 \mathrm{~h}$. After cooling to room temperature, $10 \mathrm{mg}$ of the as-prepared $\mathrm{g}-\mathrm{C}_{3} \mathrm{~N}_{4}$ sample was transferred into a $25 \mathrm{~mL}$ flask containing a certain amount of water. Then the desired amount of $\mathrm{AgNO}_{3}$ aqueous solution $(5.50 \mathrm{mg} / \mathrm{mL})$ and $\mathrm{CoCl}_{2}$ solution $(8.67 \mathrm{mg} / \mathrm{mL})$ were added into the flask. The total volume of the solution was controlled at $4.0 \mathrm{~mL}$. Finally, the mixture was ultrasonicated for $20 \mathrm{~min}$ to get a uniform suspension. The reaction temperature was controlled at $25{ }^{\circ} \mathrm{C}$ by a water bath. $\mathrm{AB}$ aqueous solution $\left(1.0 \mathrm{mmol} \mathrm{AB}\right.$ was dissolved in $\left.1.0 \mathrm{~mL} \mathrm{H}_{2} \mathrm{O}\right)$ was rapidly injected into the reactor. During the reaction process, the volume of $\mathrm{H}_{2}$ was measured by the water-displacement method. For comparison, the molar ratio of Ag/Co was controlled at 1:9, 2:8, 3:7, 7:3, 8:2, 9:1, 10:0, and 0:10. The Ag and Co loadings determined by ICP-OES are shown in Table S1 in detail. 
For comparison, $\mathrm{Al}_{2} \mathrm{O}_{3}$ and Mobil Composition of Matter N. 41 (MCM-41) were also used as supports for depositing $\mathrm{Ag}_{0.1} \mathrm{Co}_{0.9}$ bimetallic catalysts under the same procedures. For stability tests, the catalyst was recovered from the reaction mixture and washed with water three times. Then, the catalyst was applied for the next run by adding another equivalent of $A B$ solution into the mixture. The catalytic recycling was repeated five times.

\section{Results and Discussion}

The morphology of the as-synthesized $\mathrm{Ag}_{0.1} \mathrm{Co}_{0.9} / \mathrm{g}-\mathrm{C}_{3} \mathrm{~N}_{4}$ sample was detected by TEM, and the results are shown in Figure 1. It can be seen that the particles are homogenously anchored on the support (Figure 1a). High-resolution TEM images were further recorded to confirm their syntheses. As shown in Figure $1 \mathrm{~b}$, the lattice spacing of $0.235 \mathrm{~nm}$ is ascribed to the $\mathrm{Ag}$ (111) plane [17], whereas the d-spacing of $0.246 \mathrm{~nm}$ is correlated to the $\mathrm{Co}_{3} \mathrm{O}_{4}$ (311) plane (Figure 1c). The presence of oxidized cobalt species could be assigned to the oxidation of metallic cobalt in the sample preparation. The mean particle size of the Ag and Co nanoparticles are calculated as shown in Figure 1d,e. The average sizes of $\mathrm{Ag}$ and $\mathrm{Co}_{3} \mathrm{O}_{4}$ nanoparticles are calculated to be $9.04 \mathrm{~nm}$ and $5.37 \mathrm{~nm}$, respectively. The results show that $\mathrm{Ag}$ and $\mathrm{Co}$ are successfully supported on the $\mathrm{g}-\mathrm{C}_{3} \mathrm{~N}_{4}$ support. It should be pointed out that no alloy and core-shell structure of $\mathrm{Ag}$ and Co bimetallic nanoparticles are observed in the present synthetic conditions. Figure $1 \mathrm{f}$ illustrates the XRD patterns of the as-synthesized samples. The diffraction peak located at $2 \theta=27.4^{\circ}$ is attributed to (002) crystal plane of $g-C_{3} \mathrm{~N}_{4}$, which is assigned to the characteristic inter-planar stacking conjugated aromatic structure after the polymerization of urea [26]. In the XRD patterns of $\mathrm{Ag}_{0.1} \mathrm{Co}_{0.9} / \mathrm{g}-\mathrm{C}_{3} \mathrm{~N}_{4}$, the diffraction peak detected at $2 \theta=38.26^{\circ}$ is assigned to the (111) crystal plane of Ag (JCPDS No. 89-3722). Nevertheless, no obvious characteristic peaks of cobalt species are detected.
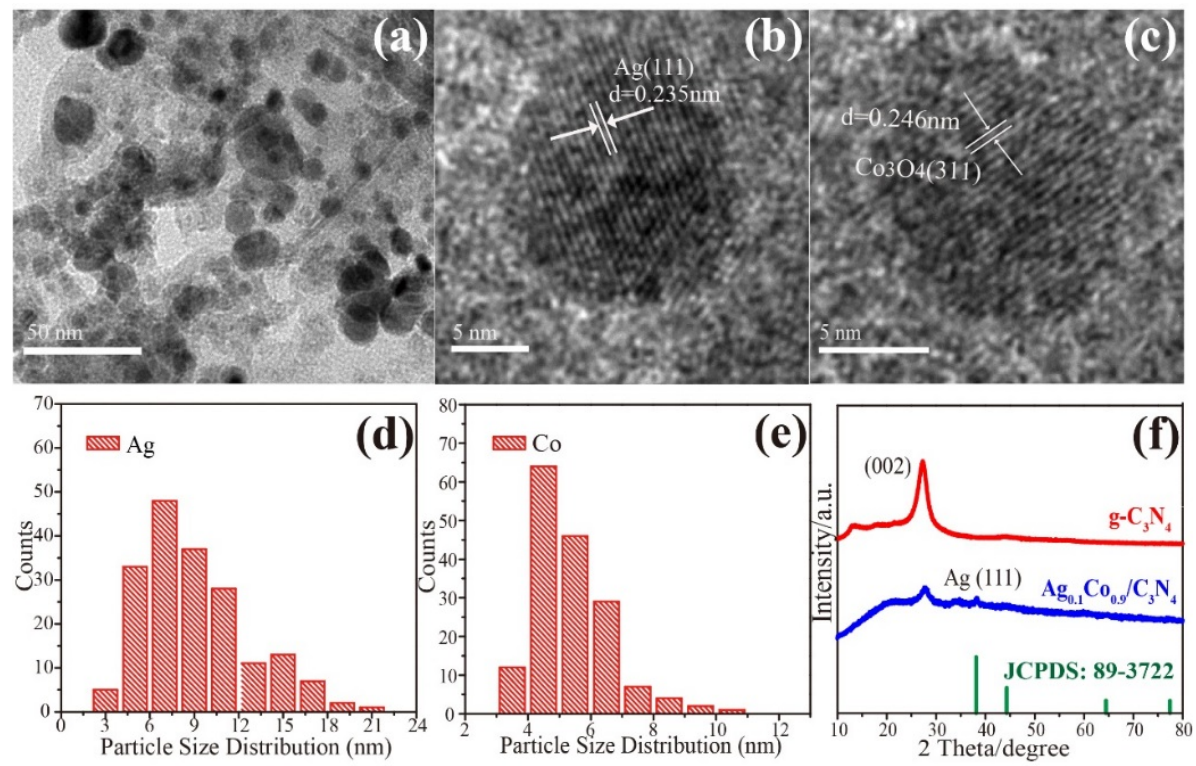

Figure 1. (a) TEM images of $\mathrm{Ag}_{0.1} \mathrm{Co}_{0.9} / \mathrm{g}-\mathrm{C}_{3} \mathrm{~N}_{4}$. HRTEM images of (b) Ag nanoparticles and $(\mathbf{c}) \mathrm{Co}_{3} \mathrm{O}_{4}$ nanoparticles. (d) Particle size distribution of Ag nanoparticles. (e) Particle size distribution of Co nanoparticles. (f) XRD patterns of $g-\mathrm{C}_{3} \mathrm{~N}_{4}$ and $\mathrm{Ag}_{0.1} \mathrm{Co}_{0.9} / \mathrm{g}-\mathrm{C}_{3} \mathrm{~N}_{4}$.

FTIR spectra was further applied to analyze the structure of the $\mathrm{g}^{-} \mathrm{C}_{3} \mathrm{~N}_{4}$ support. As displayed in Figure $2 \mathrm{a}$, a broad band situated at $3200-3500 \mathrm{~cm}^{-1}$ is detected, which is assigned to the stretching vibration modes of $\mathrm{N}-\mathrm{H}$ bonds and the surface absorbed oxygen-containing groups, such as hydroxyl groups. The observation of the $\mathrm{N}-\mathrm{H}$ stretching vibration modes verifies that the carbon nitride layer contained some uncondensed amine functional groups. Several strong bands appeared at $1246 \mathrm{~cm}^{-1}$, 
$1416 \mathrm{~cm}^{-1}$, and $1645 \mathrm{~cm}^{-1}$ correspond to typical stretching modes of the carbon-nitrogen (C-N) heterocycle. The characteristic breathing modes of the triazine units at $814 \mathrm{~cm}^{-1}$ [27] indicate the successful synthesis of $\mathrm{g}-\mathrm{C}_{3} \mathrm{~N}_{4}$ support. In addition, no apparent changes between the $\mathrm{g}-\mathrm{C}_{3} \mathrm{~N}_{4}$ and $\mathrm{Ag}_{0.1} \mathrm{Co}_{0.9} / \mathrm{g}-\mathrm{C}_{3} \mathrm{~N}_{4}$ spectra are detected, illustrating that the stabilization of $\mathrm{Ag}$ and Co do not affect the structure of the support.
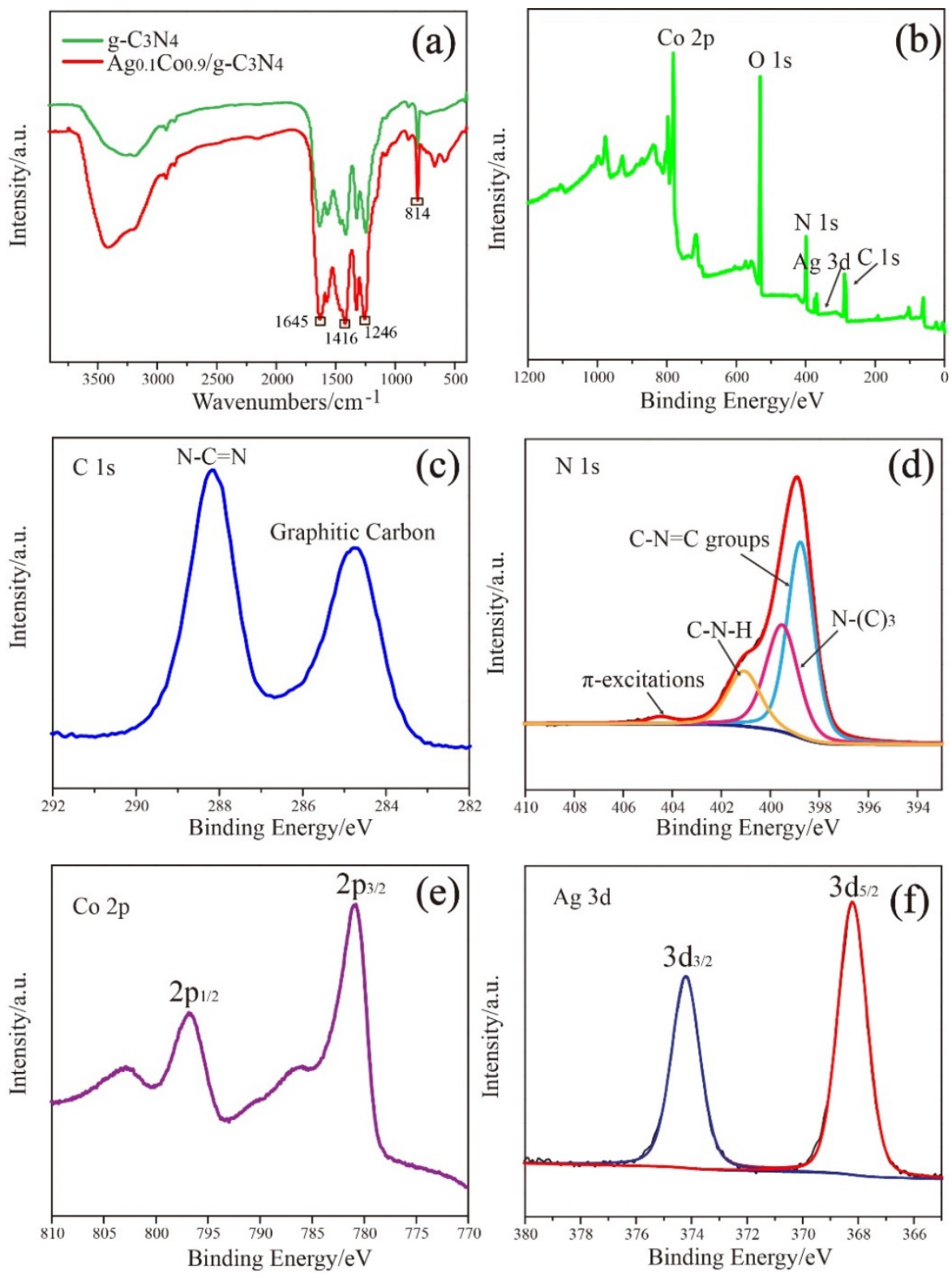

Figure 2. (a) FTIR spectra of $g-\mathrm{C}_{3} \mathrm{~N}_{4}$ and $\mathrm{Ag}_{0.1} \mathrm{Co}_{0.9} / \mathrm{g}-\mathrm{C}_{3} \mathrm{~N}_{4}$. (b) XPS of the survey scan of the catalyst. XPS spectra of (c) C 1s, (d) N 1s, (e) Co 2p, and (f) Ag 3d.

XPS characterization was employed to investigate the electronic states of the elements in $\mathrm{Ag}_{0.1} \mathrm{Co}_{0.9} / \mathrm{g}-\mathrm{C}_{3} \mathrm{~N}_{4}$. Figure $2 \mathrm{~b}$ displays the XPS survey scan of the catalyst, in which carbon, nitrogen, oxygen, silver, and cobalt elements are detected, implying the successful synthesis. According to the high-resolution XPS spectrum of C1s (Figure 2c), the presence of the $\mathrm{N}-\mathrm{C}=\mathrm{N}$ groups, as well as graphitic carbon, are verified because of the appearance of two characteristic peaks at $288.2 \mathrm{eV}$ and $284.9 \mathrm{eV}[28,29]$. With regard to the N1s spectrum (Figure 2d), the presence of C-N-C groups, the three $\mathrm{N}$-bonded $\mathrm{C}$ atoms of aromatic cycles, and the $\pi$-excitations can be confirmed through 
the observation of characteristic peaks with binding energies of $398.8 \mathrm{eV}, 400.9 \mathrm{eV}$, and $404.5 \mathrm{eV}$, respectively. The presence of $\mathrm{N}-(\mathrm{C})_{3}$ or $\mathrm{H}-\mathrm{N}-(\mathrm{C})_{2}$ groups are verified according to the XPS peak with a binding energy of $399.5 \mathrm{eV}$. [29,30]. As shown in Figure 2e, the Co 2p core-level XPS spectrum can be divided into two peaks with binding energies of $780.8 \mathrm{eV}$ and $796.8 \mathrm{eV}$, indicating the formation of $\mathrm{Co}_{3} \mathrm{O}_{4}$. The presence of oxidized cobalt is probably attributed to the oxidation of Co during the catalyst preparation since metallic cobalt is sensitive to air [5,31,32]. From the Ag $3 \mathrm{~d}$ spectrum in Figure $2 \mathrm{f}$, it can be seen that the Ag species are in the metallic states, since two distinct peaks with binding energies of 374.2 and $368.2 \mathrm{eV}$ are observed [17,33].

Figure $3 a$ shows the effect of the $\mathrm{Ag} / \mathrm{Co}$ molar ratios in $\mathrm{Ag}_{\mathrm{x}} \mathrm{Co}_{1-\mathrm{x}} / g-\mathrm{C}_{3} \mathrm{~N}_{4}$ on the hydrolysis of $\mathrm{AB}$. It is observed that $\mathrm{Ag}_{0.1} \mathrm{Co}_{0.9} / \mathrm{g}-\mathrm{C}_{3} \mathrm{~N}_{4}, \mathrm{Ag}_{0.2} \mathrm{Co}_{0.8} / \mathrm{g}-\mathrm{C}_{3} \mathrm{~N}_{4}$, and $\mathrm{Ag}_{0.3} \mathrm{Co}_{0.7} / \mathrm{g}-\mathrm{C}_{3} \mathrm{~N}_{4}$ catalysts show higher catalytic activities than other investigated catalysts, whereas the hydrolysis reaction is incomplete over the $\mathrm{Ag}_{1.0} \mathrm{Co}_{0} / \mathrm{g}-\mathrm{C}_{3} \mathrm{~N}_{4}, \mathrm{Ag}_{0} \mathrm{Co}_{1.0} / \mathrm{g}-\mathrm{C}_{3} \mathrm{~N}_{4}, \mathrm{Ag}_{0.7} \mathrm{Co}_{0.3} / \mathrm{g}-\mathrm{C}_{3} \mathrm{~N}_{4}$, and $\mathrm{Ag}_{0.9} \mathrm{Co}_{0.1} / \mathrm{g}-\mathrm{C}_{3} \mathrm{~N}_{4}$ catalysts. Especially, the highest TOF of $249.09 \mathrm{~mol} \mathrm{H}_{2} \cdot\left(\mathrm{mol}_{\mathrm{Ag}} \cdot \mathrm{min}\right)^{-1}$ is observed with the $\mathrm{Ag}_{0.1} \mathrm{Co}_{0.9} / \mathrm{g}-\mathrm{C}_{3} \mathrm{~N}_{4}$ catalyst, indicating its high catalytic activity toward the hydrolysis of $\mathrm{AB}$. To obtain detailed information on their catalytic performances, the XRD patterns of the investigated samples were recorded, and the results are shown in Figure S1. From the XRD patterns, it can be seen that the strong and sharp diffraction peaks of $\mathrm{Ag}$ are detected with the decrease of Co content, indicating that the generation of large Ag nanoparticles. The broad and weak characteristic peaks of Ag observed in $\mathrm{Ag}_{0.1} \mathrm{Co}_{0.9} / \mathrm{g}-\mathrm{C}_{3} \mathrm{~N}_{4}$ indicate the formation of smaller $\mathrm{Ag}$ nanoparticles with higher Co contents. The results verify that the addition of more Co species is benefited to the control of Ag particle size in the synthesized samples. It is well-established that the small-sized metal nanoparticles can provide more highly surface-active sites for catalytic applications. Therefore, the presence of small Ag nanoparticles in $\mathrm{Ag}_{0.1} \mathrm{Co}_{0.9} / \mathrm{g}-\mathrm{C}_{3} \mathrm{~N}_{4}$ are responsible for the high catalytic activity. In addition, the $\mathrm{Ag}_{0.1} \mathrm{Co}_{0.9} / \mathrm{g}-\mathrm{C}_{3} \mathrm{~N}_{4}$ catalyst also exhibits much higher catalytic activity compared with the reported results, such as Ag@Co/graphene $\left(102.4 \mathrm{~mol} \mathrm{H}_{2} \cdot\left(\mathrm{mol}_{\mathrm{Ag}} \cdot \mathrm{min}\right)^{-1}\right)$ [17], Ag@Ni/graphene $\left(77 \mathrm{~mol} \mathrm{H}_{2} \cdot\left(\mathrm{mol}_{\mathrm{Ag}} \cdot \mathrm{min}\right)^{-1}\right)$ [17], $\mathrm{Ru} @ \mathrm{Al}_{2} \mathrm{O}_{3}\left(39.6 \mathrm{~mol} \mathrm{H}_{2} \cdot\left(\mathrm{mol}_{\mathrm{Ru}} \cdot \mathrm{min}\right)^{-1}\right)$ [34], $\mathrm{Ag} @ \mathrm{C} @ \mathrm{Co}(8.93 \mathrm{~mol}$ $\left.\mathrm{H}_{2} \cdot\left(\mathrm{mol}_{\mathrm{Ag}} \cdot \mathrm{min}\right)^{-1}\right)$ [33], $\mathrm{RuCo} @ \mathrm{Al}_{2} \mathrm{O}_{3}\left(32.9 \mathrm{~mol} \mathrm{H}_{2} \cdot\left(\mathrm{mol}_{\mathrm{Ru}} \cdot \mathrm{min}\right)^{-1}\right)$ [14], Pd@Co/graphene (408.9 mol $\left.\mathrm{H}_{2} \cdot\left(\mathrm{mol}_{\mathrm{Pd}} \cdot \mathrm{min}\right)^{-1}\right)$ [16], and $\mathrm{Ni}_{0.74} \mathrm{Ru}_{0.26}$ alloy $\left(194.8 \mathrm{~mol} \mathrm{H}_{2} \cdot\left(\mathrm{mol}_{\mathrm{Ru}} \cdot \mathrm{min}\right)^{-1}\right)$ [13] (Figure 4e).
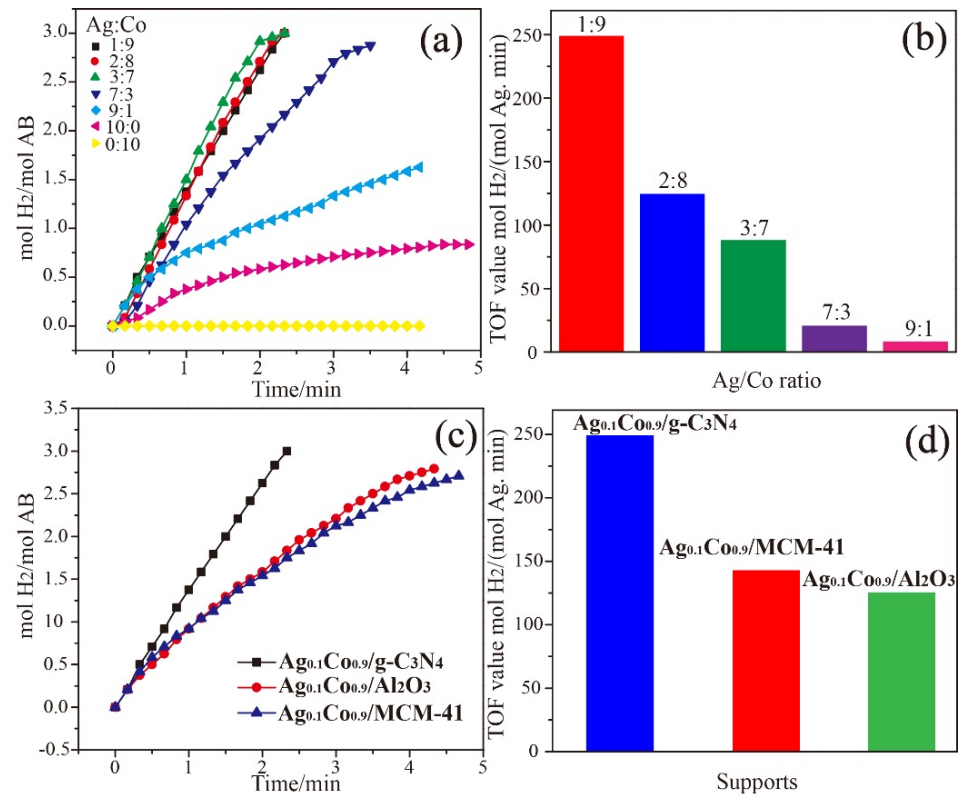

Figure 3. (a) The plots of $\mathrm{mol} \mathrm{H}_{2} / \mathrm{mol} \mathrm{AB}$ versus time for different ratios of $\mathrm{Ag} / \mathrm{Co}$. (b) TOF values of different ratios of $\mathrm{Ag} / \mathrm{Co}$. (c) The plots of $\mathrm{mol} \mathrm{H}_{2} / \mathrm{mol} \mathrm{AB}$ versus time graph for different catalysts. (d) TOF values of different catalysts toward the hydrolysis of AB. 

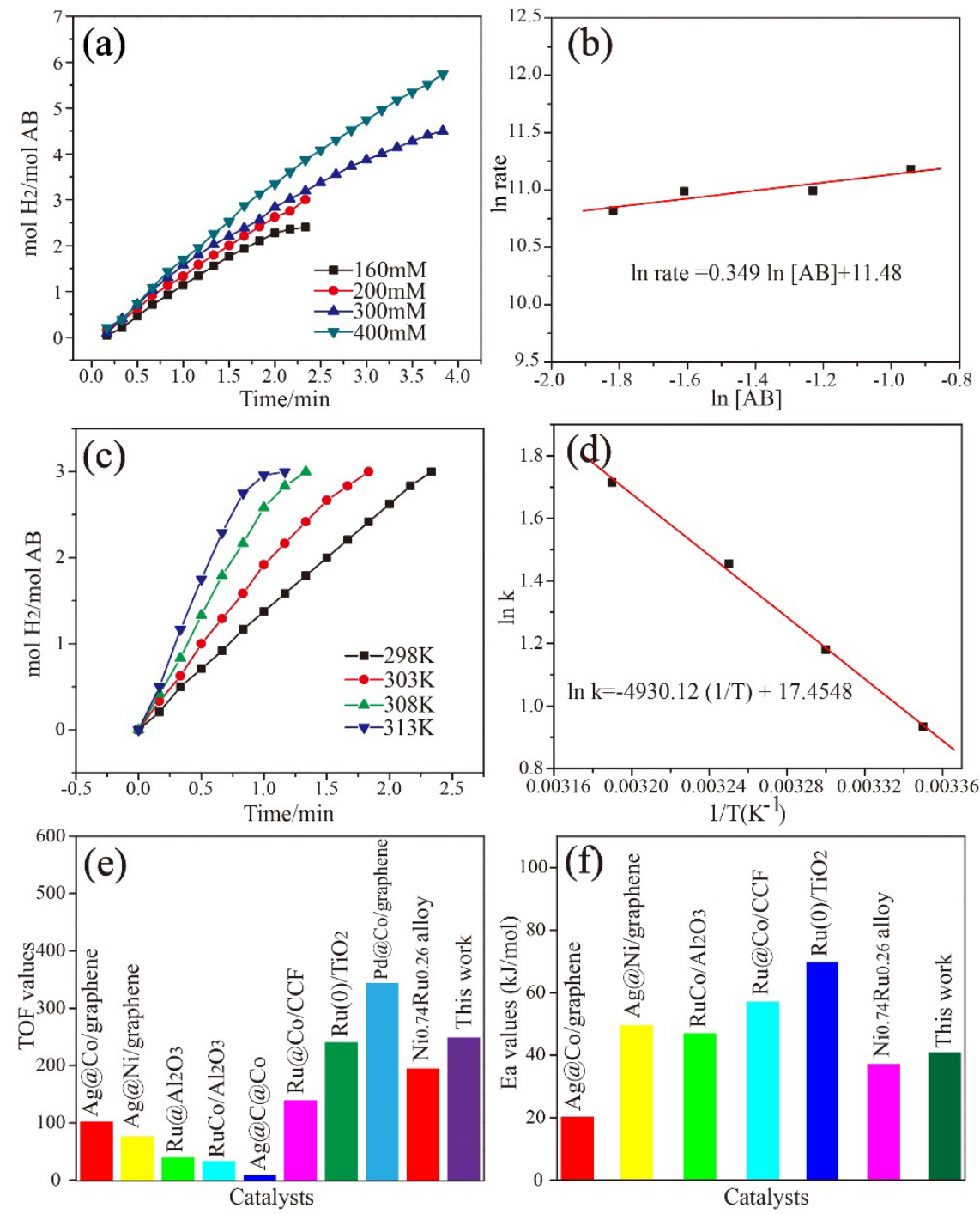

Figure 4. (a) The plots of $\mathrm{mol} \mathrm{H}_{2} / \mathrm{mol} \mathrm{AB}$ versus reaction time at different $\mathrm{AB}$ concentrations. (b) Plot of $\ln$ (rate) versus $\ln [\mathrm{AB}]$. (c) The plots of $\mathrm{mol} \mathrm{H}_{2} / \mathrm{mol} \mathrm{AB}$ versus time for different temperatures. (d) The Arrhenius plot for the hydrogen release of AB. (e,f) Comparison of TOF values and $E_{a}$ values among this work and the reported literature.

We also prepared the MCM-41 and $\mathrm{Al}_{2} \mathrm{O}_{3}$ supported $\mathrm{Ag}_{0.1} \mathrm{Co}_{0.9}$ bimetallic nanoparticles and investigated their catalytic activity toward the hydrolysis of $\mathrm{AB}$. From Figure $3 \mathrm{c}$, we can see that the $\mathrm{Ag}_{0.1} \mathrm{Co}_{0.9} / \mathrm{g}-\mathrm{C}_{3} \mathrm{~N}_{4}$ can quickly catalyze the complete hydrolysis of $\mathrm{AB}$ in less than $2.5 \mathrm{~min}$. However, $\mathrm{Ag}_{0.1} \mathrm{Co}_{0.9} / \mathrm{MCM}-41$ and $\mathrm{Ag}_{0.1} \mathrm{Co}_{0.9} / \mathrm{Al}_{2} \mathrm{O}_{3}$ require longer time to complete the hydrolysis reaction. As exhibited in Figure 3d, $\mathrm{Ag}_{0.1} \mathrm{Co}_{0.9} / \mathrm{g}-\mathrm{C}_{3} \mathrm{~N}_{4}$ has a much higher catalytic activity with a TOF of $249.09 \mathrm{~mol} \mathrm{H}_{2} \cdot\left(\mathrm{mol}_{\mathrm{Ag}} \cdot \mathrm{min}\right)^{-1}$, while the TOF values of $\mathrm{Ag}_{0.1} \mathrm{Co}_{0.9} / \mathrm{MCM}-41$ and $\mathrm{Ag}_{0.1} \mathrm{Co}_{0.9} / \mathrm{Al}_{2} \mathrm{O}_{3}$ are 143.1 and $124.81 \mathrm{~mol} \mathrm{H}_{2} \cdot\left(\mathrm{mol}_{\mathrm{Ag}} \cdot \mathrm{min}\right)^{-1}$, respectively. These results confirm that the superior catalytic performance of $\mathrm{Ag}_{0.1} \mathrm{Co}_{0.9} / \mathrm{g}-\mathrm{C}_{3} \mathrm{~N}_{4}$ catalyst is correlated with the nature of the $\mathrm{g}-\mathrm{C}_{3} \mathrm{~N}_{4}$ support.

Kinetic studies of $\mathrm{AB}$ hydrolysis over $\mathrm{Ag}_{0.1} \mathrm{Co}_{0.9} / \mathrm{g}-\mathrm{C}_{3} \mathrm{~N}_{4}$ catalyst were performed at different substrate concentrations and reaction temperatures. Figure $4 a$ displays the effect of $\mathrm{AB}$ concentration on the catalytic hydrolysis of $\mathrm{AB}$ over the $\mathrm{Ag}_{0.1} \mathrm{Co}_{0.9} / \mathrm{g}-\mathrm{C}_{3} \mathrm{~N}_{4}$ catalyst. The reaction rate of the initial hydrogen evolution is acquired by fitting the linear part of each plot. Figure $4 \mathrm{~b}$ shows the plots of $\mathrm{ln}$ (rate) vs. $\ln (\mathrm{AB})$. The fitting line with a slope of 0.349 indicates that the hydrolysis mechanism for the hydrolysis of $\mathrm{AB}$ with $\mathrm{AgCo} / \mathrm{g}-\mathrm{C}_{3} \mathrm{~N}_{4}$ catalyst is differentiated with the literature [5,10]. We further 
performed the hydrolysis of $\mathrm{AB}$ under varied reaction temperatures to calculate the activation energy $\left(E_{a}\right)$ value of the hydrolysis reaction over $\mathrm{Ag}_{0.1} \mathrm{Co}_{0.9} / \mathrm{g}-\mathrm{C}_{3} \mathrm{~N}_{4}$. Notably, the reaction temperature possesses a profound effect on the hydrolysis reaction. As illustrated in Figure $4 c$, the time of completion of the reaction toward hydrogen evolution from the hydrolysis of $\mathrm{AB}$ decreases with the increase of the reaction temperature. Consequently, the $E_{a}$ value of the catalytic hydrolysis of $A B$ over $\mathrm{Ag}_{0.1} \mathrm{Co}_{0.9} / \mathrm{g}-\mathrm{C}_{3} \mathrm{~N}_{4}$ catalyst is $40.91 \mathrm{~kJ} / \mathrm{mol}$, calculated by fitting the Arrhenius plot in Figure $4 \mathrm{~d}$. This value was smaller than most of the reported literature as listed in Figure $4 \mathrm{f}$, such as $\mathrm{Ru}_{\mathrm{A}} \mathrm{Al}_{2} \mathrm{O}_{3}$ (48 kJ/mol) [34], RuCo@ $\mathrm{Al}_{2} \mathrm{O}_{3}$ (47 kJ/mol) [14], Ru@Co/CCF (57.02 kJ/mol) [35], and $\mathrm{Ru}(0) / \mathrm{TiO}_{2}$ (70 kJ/mol) [12], but higher than Ag@Co/graphene $(20.3 \mathrm{~kJ} / \mathrm{mol})$ [17] and $\mathrm{Ni}_{0.74} \mathrm{Ru}_{0.26}$ alloy (37.18 $\mathrm{kJ} / \mathrm{mol}$ ) [13]. The lower activation energy indicates the favorable reaction kinetic of AB hydrolysis catalyzed by the $\mathrm{Ag}_{0.1} \mathrm{Co}_{0.9} / \mathrm{g}-\mathrm{C}_{3} \mathrm{~N}_{4}$ catalyst.

Figure 5 a shows the stability and reusability of the catalyst. Notably, the catalyst still can release three equivalent $\mathrm{H}_{2}$ per mole $\mathrm{AB}$ after recycled for five times, indicating the good recyclability of $\mathrm{Ag}_{0.1} \mathrm{Co}_{0.9} / \mathrm{g}-\mathrm{C}_{3} \mathrm{~N}_{4}$. However, the catalyst undergoes a slight loss of activity with the increase of recycling tests. The TOF value of the fifth run is $129.16 \mathrm{~mol} \mathrm{H}_{2} \cdot\left(\mathrm{mol}_{\mathrm{Ag}} \cdot \mathrm{min}\right)^{-1}$, preserving $52 \%$ of the initial value. To obtain more information on the catalytic activity loss, the liquid of the reaction mixture after each run was separated for the catalytic test. The results indicate that no hydrogen evolution is observed. Therefore, TEM was performed to analyze the structure and morphology of the recycled $\mathrm{Ag}_{0.1} \mathrm{Co}_{0.9} / \mathrm{g}-\mathrm{C}_{3} \mathrm{~N}_{4}$ catalyst. It is observed that $\mathrm{Ag}$ and Co nanoparticles on the $\mathrm{g}-\mathrm{C}_{3} \mathrm{~N}_{4}$ surface maintain their morphologies after recycling (Figure S2a) with the mean size of $9.45 \mathrm{~nm}$ and $5.60 \mathrm{~nm}$ (Figure S2b,c), indicating that the deactivation of the catalyst is presumably ascribed to the slight increase of the particle size during the recycling and the probable increase of the viscosity of the reaction solution and/or the increasing metaborate concentration during AB hydrolysis.
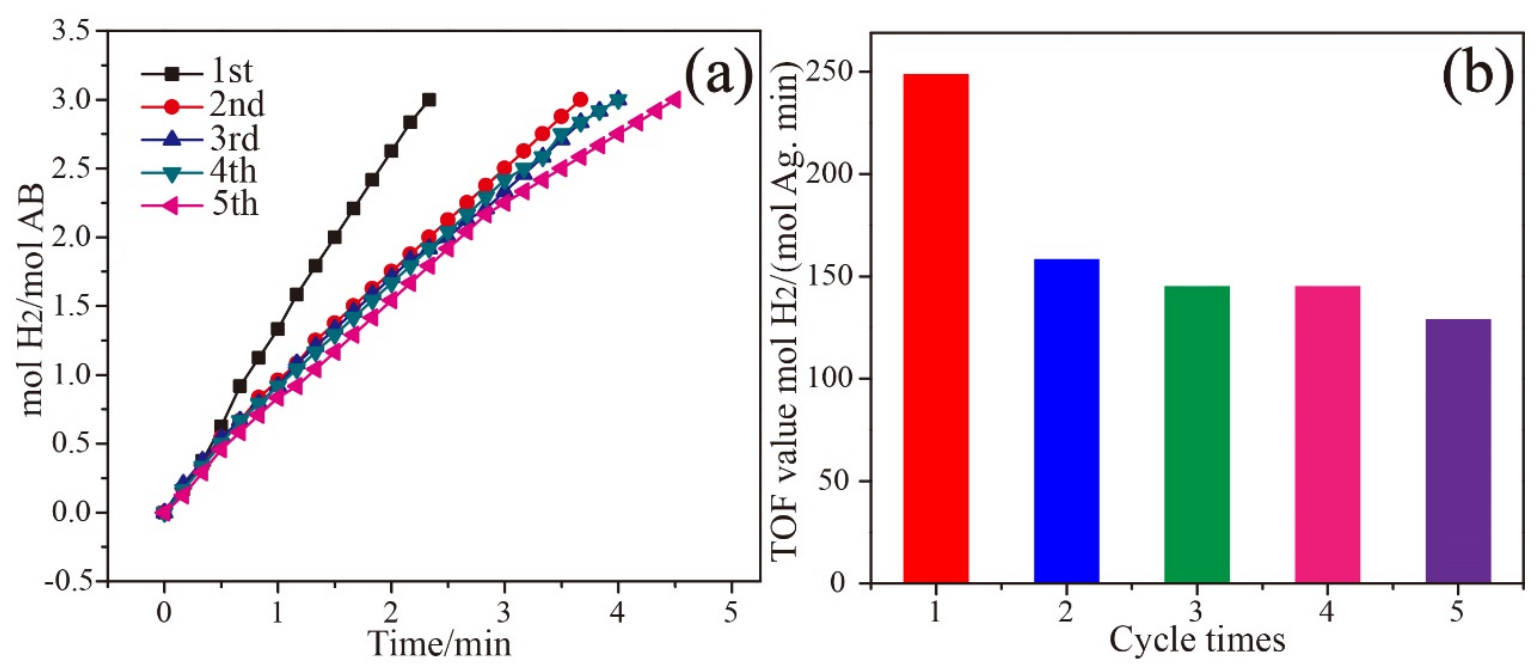

Figure 5. (a) The plots of $\mathrm{mol} \mathrm{H} / 2 / \mathrm{mol} \mathrm{AB}$ versus time during the catalyst stability tests. (b) The TOF values for $\mathrm{AB}$ hydrolysis over $\mathrm{Ag}_{0.1} \mathrm{Co}_{0.9} / \mathrm{g}-\mathrm{C}_{3} \mathrm{~N}_{4}$ after each cycle.

\section{Conclusions}

In summary, the $\mathrm{AgCo} / \mathrm{g}-\mathrm{C}_{3} \mathrm{~N}_{4}$ nanoparticles were prepared via the co-reduction of the aqueous solution of silver nitrate and cobalt chloride. The bimetallic catalyst showed synergistic effect and excellent catalytic properties for the hydrolysis of $\mathrm{AB}$ to produce hydrogen at $25{ }^{\circ} \mathrm{C}$. The $\mathrm{Ag}_{0.1} \mathrm{Co}_{0.9} / \mathrm{g}-\mathrm{C}_{3} \mathrm{~N}_{4}$ showed highest activity with a TOF of $249.02 \mathrm{~mol} \mathrm{H}_{2} \cdot\left(\mathrm{mol}_{\mathrm{Ag}} \cdot \mathrm{min}\right)^{-1}$ and a lower $E_{a}$ of $40.91 \mathrm{~kJ} / \mathrm{mol}$. The good stability and reusability indicate that the present catalyst is a promising material for the hydrolysis of $\mathrm{AB}$ to yield hydrogen. 
Supplementary Materials: The following are available online at http:/ / www.mdpi.com/2079-4991/8/5/280/ s1. Figure S1: the XRD patterns of the $\mathrm{g}_{-} \mathrm{C}_{3} \mathrm{~N}_{4}$ and $A \mathrm{~g}_{\mathrm{X}} \mathrm{Co}_{1-\mathrm{X}} / \mathrm{g}-\mathrm{C}_{3} \mathrm{~N}_{4}$, Figure S2: (a) the TEM image of $\mathrm{Ag}_{0.1} \mathrm{Co}_{0.9} / \mathrm{g}-\mathrm{C}_{3} \mathrm{~N}_{4}$ after five recycling runs. (b) Particle size distribution of Ag nanoparticles after 5 recycling runs. (c) Particle size distribution of Co nanoparticles after 5 recycling runs, Table S1: Ag and Co loadings determined by ICP-OES.

Author Contributions: Qi Wang, Caili Xu, and Mei Ming prepared and characterized the samples. Yingchun Yang, $\mathrm{Bin} \mathrm{Xu}$, and Jie $\mathrm{Wu}$ contributed reagents/materials/analysis tools. Guangyin Fan and Yi Wang designed the experiments and wrote the paper. Yun Zhang provided useful discussion.

Funding: This work was financially supported by the Sichuan Youth Science and Technology Foundation (2016JQ0052), the National Natural Science Foundation of China (21777109), and the Opening Project of Key Laboratory of Green Chemistry of Sichuan Institutes of Higher Education (LZJ1603).

Conflicts of Interest: The authors declare no conflict of interest.

\section{References}

1. Hu, M.; Wang, H.; Wang, Y.; Zhang, Y.; Wu, J.; Xu, B.; Gao, D.; Bi, J.; Fana, G. Alumina nanofiber-stabilized ruthenium nanoparticles: Highly efficient catalytic materials for hydrogen evolution from ammonia borane hydrolysis. Int. J. Hydrogen Energy 2017, 42, 24142-24149. [CrossRef]

2. Nunes, H.X.; Ferreira, M.J.F.; Rangel, C.M.; Pinto, A.M.F.R. Hydrogen generation and storage by aqueous sodium borohydride $\left(\mathrm{NaBH}_{4}\right)$ hydrolysis for small portable fuel cells $\left(\mathrm{H}_{2}\right.$-PEMFC). Int. J. Hydrogen Energy 2016, 41, 15426-15432. [CrossRef]

3. Li, X.; Fan, G.; Zeng, C. Synthesis of ruthenium nanoparticles deposited on graphene-like transition metal carbide as an effective catalyst for the hydrolysis of sodium borohydride. Int. J. Hydrogen Energy 2014, 39, 14927-14934. [CrossRef]

4. Ai, L.; Liu, X.; Jiang, J. Synthesis of loofah sponge carbon supported bimetallic silver-cobalt nanoparticles with enhanced catalytic activity towards hydrogen generation from sodium borohydride hydrolysis. J. Alloy. Compd. 2015, 625, 164-170. [CrossRef]

5. Li, X.; Zeng, C.; Fan, G. Magnetic RuCo nanoparticles supported on two-dimensional titanium carbide as highly active catalysts for the hydrolysis of ammonia borane. Int. J. Hydrogen Energy 2015, 40, 9217-9224. [CrossRef]

6. Li, X.; Zeng, C.; Fan, G. Ultrafast hydrogen generation from the hydrolysis of ammonia borane catalyzed by highly efficient bimetallic RuNi nanoparticles stabilized on $\mathrm{Ti}_{3} \mathrm{C}_{2} \mathrm{X}_{2}(\mathrm{X}=\mathrm{OH}$ and/or $\mathrm{F})$. Int. J. Hydrogen Energy 2015, 40, 3883-3891. [CrossRef]

7. Ma, Y.; Li, X.; Zhang, Y.; Chen, L.; Wu, J.; Gao, D.; Bi, J.; Fana, G. Ruthenium nanoparticles supported on $\mathrm{TiO}_{2}$ (B) nanotubes: Effective catalysts in hydrogen evolution from the hydrolysis of ammonia borane. J. Alloy. Compd. 2017, 708, 270-277. [CrossRef]

8. Zhu, Q.-L.; Tsumori, N.; Xu, Q. Sodium hydroxide-assisted growth of uniform Pd nanoparticles on nanoporous carbon MSC-30 for efficient and complete dehydrogenation of formic acid under ambient conditions. Chem. Sci. 2014, 5, 195-199. [CrossRef]

9. Wang, S.; Zhang, D.; Ma, Y.; Zhang, H.; Gao, J.; Nie, Y.; Sun, X. Aqueous solution synthesis of Pt-M (M=Fe, Co. Ni) bimetallic nanoparticles and their catalysis for the hydrolytic dehydrogenation of ammonia borane. ACS Appl. Mater. Interfaces 2014, 6, 12429-12435. [CrossRef] [PubMed]

10. Yang, X.; Cheng, F.; Liang, J.; Tao, Z.; Chen, J. Pt $t_{x} \mathrm{Ni}_{1-\mathrm{x}}$ nanoparticles as catalysts for hydrogen generation from hydrolysis of ammonia borane. Int. J. Hydrogen Energy 2009, 34, 8785-8791. [CrossRef]

11. Chandra, M.; Xu, Q. A high-performance hydrogen generation system: Transition metal-catalyzed dissociation and hydrolysis of ammonia-borane. J. Power Sources 2006, 156, 190-194. [CrossRef]

12. Akbayrak, S.; Tanyıldızı, S.; Morkan, İ.; Özkar, S. Ruthenium(0) nanoparticles supported on nanotitania as highly active and reusable catalyst in hydrogen generation from the hydrolysis of ammonia borane. Int. J. Hydrogen Energy 2014, 39, 9628-9637. [CrossRef]

13. Chen, G.; Desinan, S.; Rosei, R.; Rosei, F.; Ma, D. Synthesis of Ni-Ru alloy nanoparticles and their high catalytic activity in dehydrogenation of ammonia borane. Chem. Eur. J. 2012, 18, 7925-7930. [CrossRef] [PubMed] 
14. Rachiero, G.P.; Demirci, U.B.; Miele, P. Bimetallic RuCo and RuCu catalysts supported on $\gamma-\mathrm{Al}_{2} \mathrm{O}_{3}$. A comparative study of their activity in hydrolysis of ammonia-borane. Int. J. Hydrogen Energy 2011, 36, 7051-7065. [CrossRef]

15. Metin, Ö.; Şahin, Ş.; Özkar, S. Water-soluble poly(4-styrenesulfonic acid-co-maleic acid) stabilized ruthenium(0) and palladium(0) nanoclusters as highly active catalysts in hydrogen generation from the hydrolysis of ammonia-borane. Int. J. Hydrogen Energy 2009, 34, 6304-6313. [CrossRef]

16. Wang, J.; Qin, Y.-L.; Liu, X.; Zhang, X.-B. In situ synthesis of magnetically recyclable graphene-supported Pd@Co. core-shell nanoparticles as efficient catalysts for hydrolytic dehydrogenation of ammonia borane. J. Mater. Chem. 2012, 22, 12468-12470. [CrossRef]

17. Yang, L.; Luo, W.; Cheng, G. Graphene-supported Ag-based core-shell nanoparticles for hydrogen generation in hydrolysis of ammonia borane and methylamine borane. ACS Appl. Mater. Interfaces 2013, 5, 8231-8240. [CrossRef] [PubMed]

18. Li, J.; Zhu, Q.L.; Xu, Q. Highly active AuCo alloy nanoparticles encapsulated in the pores of metal-organic frameworks for hydrolytic dehydrogenation of ammonia borane. Chem. Commun. 2014, 50, 5899-5901. [CrossRef] [PubMed]

19. Guo, L.-T.; Cai, Y.-Y.; Ge, J.-M.; Zhang, Y.-N.; Gong, L.-H.; Li, X.-H.; Wang, K.X.; Ren, Q.Z.; Su, J.; Chen, J.S. Multifunctional Au-Co@CN nanocatalyst for highly efficient hydrolysis of ammonia borane. ACS Catal. 2014, 5, 388-392. [CrossRef]

20. Ming, M.; Ren, Y.R.; Hu, M.; Zhang, Y.; Sun, T.; Ma, Y.L.; Li, X.J.; Jiang, W.D.; Gao, D.J.; Bi, J.; et al. Promoted effect of alkalization on the catalytic performance of $\mathrm{Rh} / \mathrm{alk}_{-} \mathrm{Ti}_{3} \mathrm{C}_{2} \mathrm{X}_{2}(\mathrm{X}=\mathrm{O}, \mathrm{F})$ for the hydrodechlorination of chlorophenols in base-free aqueous medium. Appl. Catal. B 2017, 210, 462-469. [CrossRef]

21. Wang, A.; Wang, C.; Fu, L.; Wong-Ng, W.; Lan, Y. Recent advances of graphitic carbon nitride-based structures and applications in catalyst, sensing, imaging, and LEDs. Nano Micro Lett. 2017, 9, 47-68. [CrossRef]

22. Zheng, Y.; Jiao, Y.; Chen, J.; Liu, J.; Liang, J.; Du, A.; Zhang, W.; Zhu, Z.; Smith, S.C.; Jaroniec, M.; et al. Nanoporous graphitic- $\mathrm{C}_{3} \mathrm{~N}_{4} @$ carbon metal-free electrocatalysts for highly efficient oxygen reduction. J. Am. Chem. Soc. 2011, 133, 20116-20119. [CrossRef] [PubMed]

23. Liu, Q.; Zhang, J. Graphene supported Co-g- $\mathrm{C}_{3} \mathrm{~N}_{4}$ as a novel metal-macrocyclic electrocatalyst for the oxygen reduction reaction in fuel cells. Langmuir 2013, 29, 3821-3828. [CrossRef] [PubMed]

24. Yan, S.C.; Li, Z.S.; Zou, Z.G. Photodegradation performance of $\mathrm{g}-\mathrm{C}_{3} \mathrm{~N}_{4}$ fabricated by directly heating melamine. Langmuir 2009, 25, 10397-10401. [CrossRef] [PubMed]

25. Xiang, Q.; Yu, J.; Jaroniec, M. Preparation and enhanced visible-light photocatalytic $\mathrm{H}_{2}$-production activity of graphene $/ \mathrm{C}_{3} \mathrm{~N}_{4}$ composites. J. Phys. Chem. C 2011, 115, 7355-7363. [CrossRef]

26. Kim, M.; Hwang, S.; Yu, J.-S. Novel ordered nanoporous graphitic $\mathrm{C}_{3} \mathrm{~N}_{4}$ as a support for Pt-Ru anode catalyst in direct methanol fuel cell. J. Mater. Chem. 2007, 17, 1656-1659. [CrossRef]

27. Samanta, S.; Martha, S.; Parida, K. Facile Synthesis of Au/g- $\mathrm{C}_{3} \mathrm{~N}_{4}$ Nanocomposites: An inorganic/organic hybrid plasmonic photocatalyst with enhanced hydrogen gas evolution under visible-light irradiation. ChemCatChem 2014, 6, 1453-1462. [CrossRef]

28. Raymundo-Piñero, E.; Cazorla-Amorós, D.; Linares-Solano, A.; Find, J.; Wild, U.; Schlögl, R. Structural characterization of $\mathrm{N}$-containing activated carbon fibers prepared from a low softening point petroleum pitch and a melamine resin. Carbon 2014, 40, 597-608. [CrossRef]

29. Liu, J.; Zhang, T.; Wang, Z.; Dawson, G.; Chen, W. Simple pyrolysis of urea into graphitic carbon nitride with recyclable adsorption and photocatalytic activity. J. Mater. Chem. 2011, 21, 14398-14401. [CrossRef]

30. Kundu, S.; Xia, W.; Busser, W.; Becker, M.; Schmidt, D.A.; Havenith, M.; Muhler, M. The formation of nitrogen-containing functional groups on carbon nanotube surfaces: a quantitative XPS and TPD study. Phys. Chem. Chem. Phys. 2010, 12, 4351-4359. [CrossRef] [PubMed]

31. Feng, W.; Yang, L.; Cao, N.; Du, C.; Dai, H.; Luo, W.; Cheng, G. In situ facile synthesis of bimetallic CoNi catalyst supported on graphene for hydrolytic dehydrogenation of amine borane. Int. J. Hydrogen Energy 2014, 39, 3371-3380. [CrossRef]

32. Qiu, F.; Li, L.; Liu, G.; Wang, Y.; Wang, Y.; An, C.; Xu, Y.; Xu, C.; Wang, Y.; Jiao, L.; et al. In situ synthesized $\mathrm{Fe}-\mathrm{Co} / \mathrm{C}$ nano-alloys as catalysts for the hydrolysis of ammonia borane. Int. J. Hydrogen Energy 2013, 38, 3241-3249. [CrossRef] 
33. Sun, B.; Wen, M.; Wu, Q.; Peng, J. Oriented growth and assembly of Ag@C@Co. pentagonalprism nanocables and their highly sctive selected catalysis along the edges for dehydrogenation. Adv. Funct. Mater. 2012, 22, 2860-2866. [CrossRef]

34. Can, H.; Metin, Ö. A facile synthesis of nearly monodisperse ruthenium nanoparticles and their catalysis in the hydrolytic dehydrogenation of ammonia borane for chemical hydrogen storage. Appl. Catal. B 2012, 125, 304-310. [CrossRef]

35. Yang, J.; Cui, Z.; Ma, J.; Dong, Z. Ru coated Co. nanoparticles decorated on cotton derived carbon fibers as a highly efficient and magnetically recyclable catalyst for hydrogen generation from ammonia borane. Int. J. Hydrogen Energy 2018, 43, 1355-1364. [CrossRef]

(C) 2018 by the authors. Licensee MDPI, Basel, Switzerland. This article is an open access article distributed under the terms and conditions of the Creative Commons Attribution (CC BY) license (http://creativecommons.org/licenses/by/4.0/). 